\title{
Factors affecting mortality in patients with thorax trauma
}

\author{
Toraks travmalı olgularda mortaliteyi etkileyen faktörler
}

\author{
Şadiye EMİRCAN, ${ }^{1}$ Halil ÖZGÜÇ, ${ }^{2}$ Şule AKKÖSE AYDIN, ${ }^{3}$ \\ Fatma ÖZDEMİR, ${ }^{3}$ Özlem KÖKSAL, ${ }^{3}$ Mehtap BULUT ${ }^{4}$
}

\section{BACKGROUND}

The purpose of this study was to define the epidemiologic properties and correlation of physiological and anatomical risk factors with the mortality rate among patients with thorax trauma and to ensure early prediction of severe trauma.

\section{METHODS}

Files of 371 cases were retrospectively examined. Their initial state in the emergency department was analyzed in terms of mortality development. Age, gender, trauma mechanism, systolic blood pressure and respiration type on admission, accompanying injuries, thorax pathology, trauma scores, and treatment approaches in exitus and surviving cases were compared. Survival probabilities and unexpected mortality rates were computed using the Trauma Revised Score-Injury Severity Score (TRISS).

\section{RESULTS}

Age, hypotension, pathologic respiration, blunt injury, accompanying injury, abdominal trauma, high Injury Severity Score (ISS), and low Glasgow Coma Scale (GCS), Revised Trauma Score (RTS), and TRISS were the factors affecting mortality, and presence of blunt injuries, TRISS $<85$, ISS $>22$ and GCS $<13$ were found to be independent prognostic factors. The strongest factor indicating mortality was TRISS. Thirty-four of 307 cases with survival probability of over $50 \%$ died.

\section{CONCLUSION}

In the presence of factors affecting mortality, patients with thorax trauma should be evaluated as being in a high-risk group and treatment strategies must be aggressive. Case analysis based on the TRISS model would further reveal the mistakes and may improve patient care.

Key Words: Mortality; prognostic factors; thorax trauma; trauma scores; TRISS method.

\section{$\boldsymbol{A M A C}$}

$\mathrm{Bu}$ çalışmanın amacı, toraks yaralanması olan hastaların epidemiyolojik özelliklerini belirlemek, fizyolojik ve anatomik risk faktörlerinin mortaliteyle ilişkisini saptamak ve şiddetli travmanın erken tanınmasına olanak sağlamaktır.

\section{GEREÇ VE YÖNTEM}

Çalışmada toraks travmalı 371 olgu geriye dönük olarak incelendi. Olguların acil servise ilk başvuru durumları analiz edildi ve mortalite gelişimi açısından değerlendirildi. Ölen ve yaşayan olgular; yaş, cinsiyet, travma mekanizması, başvuru anındaki sistolik kan basıncı ve solunum karakteri, eşlik eden yaralanmalar, toraks patolojisi, travma skorları, tedavi yaklaşımları açısından karşılaştırıldı. Travma ve Yaralanma Şiddeti Ölçeği (TRISS) yöntemiyle olguların yaşama olasılıkları ve beklenmeyen ölüm oranları saptandı.

\section{BULGULAR}

Yaş, hipotansiyon, patolojik solunum, künt ve yandaş yaralanma, karın travması varlığı, yüksek Yaralanma Şiddeti Ölçeği (ISS), düşük Glasgow Koma Skalası (GKS), Revize Travma Skoru (RTS) ve TRISS mortaliteye etkili faktörler olarak bulundu. Künt yaralanma, TRISS $<85$, ISS $>22$ ve GKS $<13$ olması bağımsız prognostik faktörler olarak bulundu. Mortaliteyi göstermede en güçlü faktör TRISS olarak bulundu. TRISS analizinde yaşam olasılığ $\%$ 50'nin üstünde olan 307 olgudan 34'ü hayatını kaybetti.

\section{SONUÇ}

Mortaliteye etkili bulunan faktörlerin varlığında toraks travmalı hastalar yüksek risk grubu olarak değerlendirilip, tanı ve tedavide agresif olunmalıdır. TRISS yöntemine dayalı olarak yapılacak olgu analizleri hasta bakımında yap1lacak yanlışları daha iyi ortaya koyacak, bunların düzeltilmesine olanak sağlayacaktır.

Anahtar Sözcükler: Mortalite; prognostik faktörler; toraks travmas1; travma skorlar1; TRISS yöntemi.

\footnotetext{
${ }^{1}$ Burhan Nalbantoglu State Hospital, Lefkosa, TRNC; Departments of ${ }^{2}$ General Surgery, ${ }^{3}$ Emergency Medicine, Uludag University Faculty of Medicine, Bursa; ${ }^{4}$ Bursa Training and Research Hospital, Bursa, Turkey.
} Hastanesi, Bursa. 
Trauma remains one of the most important health issues in Turkey and worldwide. Patients with lifethreatening injuries comprise $10-15 \%$ of all patients with trauma. ${ }^{[1]}$ Twenty to twenty-five percent of trauma-associated deaths are due to thoracic trauma. ${ }^{[2]}$ Blunt thoracic traumas mostly accompany other system injuries. Serious pathologies such as rib fractures in the thorax, pneumothorax, contusion, tracheal or bronchial ruptures, large vascular injury, and air embolism occur as a result of both blunt and penetrative traumas. ${ }^{[3,4]}$ An effective, fast and integral trauma system is required to decrease trauma-related deaths. Such trauma systems have been established in developed countries. There are limited data related to trauma and thoracic trauma, since no noticeable and standard trauma organization has been established in our country.

The aim of the study was to determine the epidemiological features of thoracic injury patients to analyze the condition of patients on admission to the emergency department (ED), to determine the correlation of the physiological and anatomical risk factors with mortality and to provide the early diagnosis of severe trauma.

\section{MATERIALS AND METHODS}

In the present study, trauma files including 371 cases with thoracic trauma who were admitted to the ED of Uludag University Faculty of Medicine Hospital between 2000 and 2007 were scanned retrospectively. Patient admittance files and surgery notes of all cases were examined. Cases were retrospectively evaluated with respect to age, gender, mechanism of trauma, systolic blood pressure and respiratory rate on admission, accompanying injuries, thoracic pathology, trauma scores, treatment approaches (surgical-conservative), length of stay in the intensive care unit and in the clinic, complications, and causes of mortality. All values for trauma scores, such as Revised Trauma Score (RTS), Glasgow Coma Score (GCS), Injury Severity Score (ISS), Trauma Revised Score-Injury Severity Score (TRISS), and Abbreviated Injury Scale (AIS) were determined for the cases included in the study. ISS, clinical examination, radiological tests, and surgical records were calculated as the sum of the squares of the top three AIS (AIS-90) scores belonging to three anatomic regions; RTS was determined using data obtained at the moment of arrival to the hospital. The latest version of Champion was used for this score calculation. ${ }^{[5]}$ Survival rate for each patient was calculated using the TRISS system, and the equation below, described by Boyd et al., ${ }^{[6]}$ was used in the present calculation.

$$
\begin{aligned}
& \text { Survival probability (SP): } 1 /\left(1+\mathrm{e}^{-\mathrm{b}}\right) \text {. } \\
& \mathrm{B}=\mathrm{b}_{0}+\mathrm{b}_{1} \text { (RTS) }+\mathrm{b}_{2}(\mathrm{ISS})+\mathrm{b}_{3}(\mathrm{AGE}) .
\end{aligned}
$$

In this formula, for patients $<55$ years of age, the age coefficient was calculated as " 0 ", while for those $>55$ years of age, the age coefficient was "1". The b coefficients were derived by regression analysis from the American Major Trauma Outcome Study (MTOS) database. Exitus patients with SP of $>50$ were considered as preventable trauma death cases, while exitus patients with SP $\leq 50$ were considered as unpreventable trauma death cases.

\section{Statistical Analysis}

Statistical analysis was performed with SPSS 13.0 for Windows using chi-square and Fisher's exact chisquare tests, Mann-Whitney U test, independent t-test, and Kruskal-Wallis test. Cut-off values for risk factors were determined by performing receiver-operating characteristic (ROC) analysis. For factors found significant in the univariate analysis, multivariate analysis was applied using logistic regression analysis, and independent variables were determined. A value of $p<0.05$ was accepted as the level of significance.

\section{RESULTS}

Motor vehicle accidents were the trauma mechanism in almost half of the patients, and most of the cases were blunt thoracic trauma (85\%). The majority of the cases were male $(81.7 \%)$. The mean age was $42.1 \pm 15.7$, and $62.2 \%$ of cases were aged $20-49$ years. The systolic blood pressure on admission was $<90$ $\mathrm{mmHg}$ in $36.4 \%$ (n: 135 ) of the cases. The respiration pattern on admission was pathological in $29.1 \%$ (n: 108) of the cases (dyspnea-irregular-apnea). The patients' mean GCS, RTS and ISS scores were calculated as: $13.09 \pm 3.74,6.61 \pm 1.82$ and $21.7 \pm 17.3$, respectively. GCS was $\leq 8$ in $15 \%$ of the cases, and $39 \%$ of the cases were determined to have an ISS $\geq 25$, indicating very severe trauma (Fig. 1).

The majority of the patients had at least one organ system injury with thorax trauma (Fig. 2). The most frequent accompanying injuries included extremity $(27 \%)$, head (19\%), abdominal trauma (18\%), vertebra $(11 \%)$, and pelvic trauma $(8 \%)$. Rib fracture was the

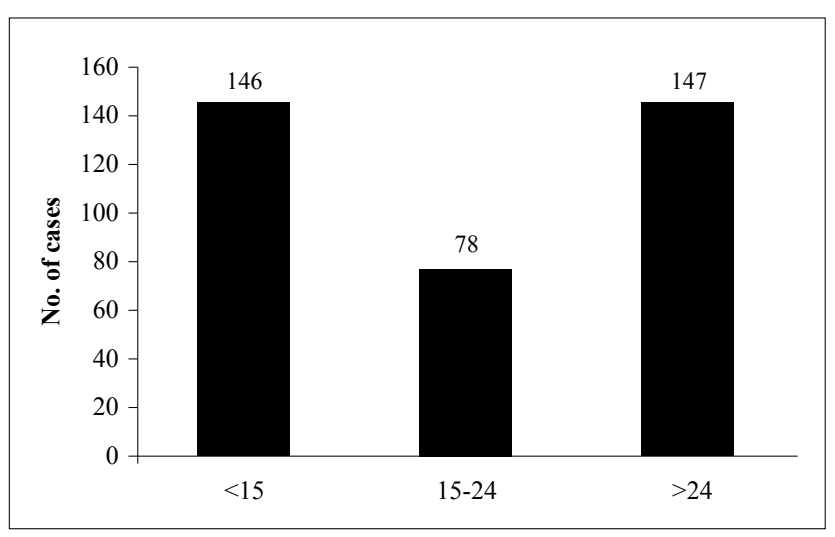

Fig. 1. Distribution of ISS among all cases. 


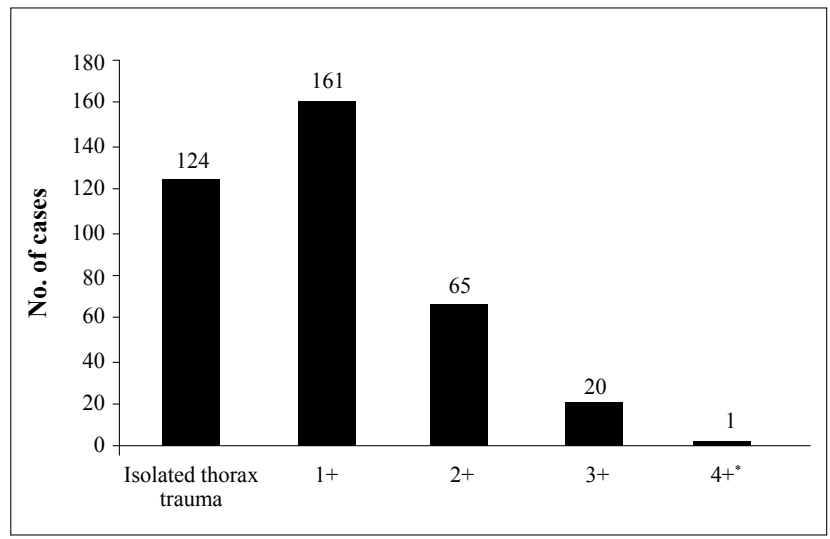

Fig. 2. Distribution of organ system injuries accompanying thorax trauma.

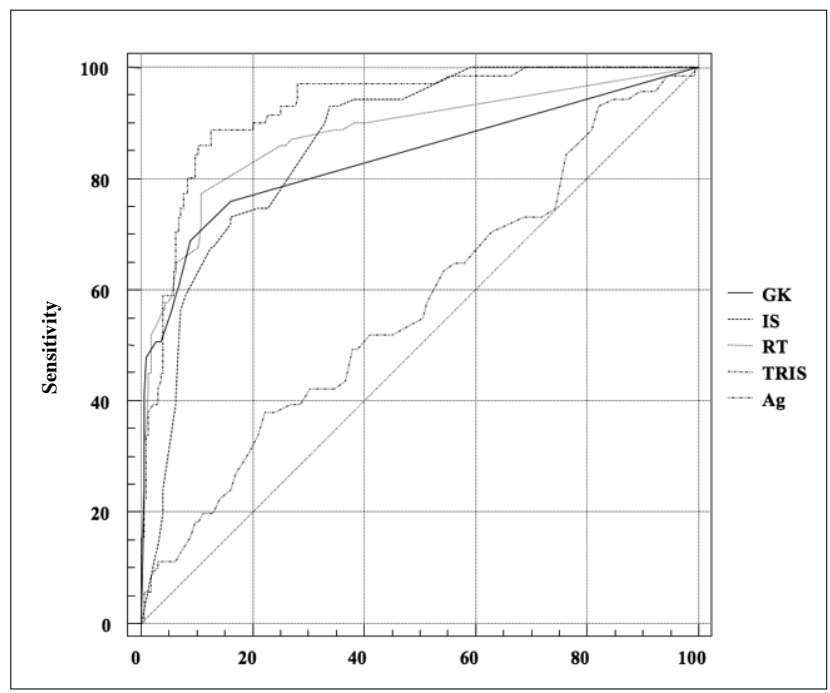

Fig. 3. ROC analysis for GCS, ISS, RTS, TRISS and age among patients with thorax trauma.

most common thoracic injury, and 109 of 214 cases with rib fracture had multiple rib fractures. Hemothorax was detected in 93 and pneumothorax in 94 of the cases. Contusion was observed in 68 , sternum fracture in 24 , diaphragm injury in 5, and cardiac pathologies such as myocardial injury in 10 of the cases. No great vessel or esophageal injuries were detected. Tube thoracostomy was applied to $232(62.5 \%)$ of the cases in the ED, and $21(5.6 \%)$ cases underwent thoracotomy. Laparotomy was applied to $38(10.2 \%)$ of the cases, craniotomy was performed in $24(6.5 \%)$, and $15(4 \%)$ cases underwent extremity surgery. Both thoracosto-
Table 1. Univariate analysis for detecting factors affecting mortality

\begin{tabular}{lccc}
\hline Factors & $\begin{array}{c}\text { Surviving cases } \\
(\mathrm{n}: 286)\end{array}$ & $\begin{array}{c}\text { Exitus cases } \\
(\mathrm{n}: 85)\end{array}$ & $\mathrm{p}$ \\
\hline *Age & $41.29 \pm 15$ & $44.9 \pm 17.9$ & 0.04 \\
*GCS & $14.37 \pm 1.98$ & $8.75 \pm 4.88$ & 0.0001 \\
*RTS & $7.27 \pm 0.97$ & $4.39 \pm 2.23$ & 0.0001 \\
*ISS & $16.7 \pm 13.8$ & $38.5 \pm 17.1$ & 0.0001 \\
*TRISS & $92.1 \pm 15.9$ & $40.8 \pm 32.2$ & 0.0001 \\
Hypotension on admission & $106(37)$ & $59(69)$ & 0.0001 \\
Respiration pattern in ED & & & \\
$\quad$ Normal & $234(81)$ & $29(34)$ & 0.0001 \\
$\quad$ Pathological & $52(19)$ & $56(66)$ & \\
Blunt trauma & $82(235)$ & $67(71)$ & 0.008 \\
Accompanying trauma & $86(61)$ & $80(94)$ & 0.0001 \\
Accompanying abdominal & & & \\
$\quad$ trauma & $173(60)$ & $73(85)$ & 0.0001 \\
\hline
\end{tabular}

my and laparotomy were performed in 4 cases. Eightyfive patients died. Age, presence of hypotension, pathological respiration pattern, blunt injury, presence of accompanying injuries, especially of abdominal trauma, high ISS, and low GCS, RTS and TRISS were determined to be effective factors of mortality in the univariate analysis (Table 1). Blunt injury, TRISS $<85$, ISS $>22$ and GCS $<13$ were independent prognostic factors in the logistic regression analysis. The strongest factor indicating mortality was TRISS (Table 2). Mortality prediction effectiveness for investigating the four scoring systems was tested using ROC analysis (Fig. 3). Cut-off values were 52 for age (AUC: 0.546, 95\% confidence interval: $0.494-0.597), 13$ for GCS (AUC: 0.88 , 95\% confidence interval: 0.797-0.874), 6.32 for RTS (AUC: $0.88,95 \%$ confidence interval: $0.843-0.912$ ), and 22 for ISS (AUC: $0.87,95 \%$ confidence interval: 0.891-0.945). Among these factors, TRISS was determined as the superior factor to predict mortality $(\mathrm{p}<0.05)$. SP was $>50 \%$ in TRISS analysis in 307 patients; however, 34 of them died, and these cases were evaluated as unexpected sudden deaths. Distribution of these cases in terms of TRISS and the number of exitus and surviving cases in accordance with these distributions are shown in Fig. 4.

\section{DISCUSSION}

In the present study, in which cases of thoracic trauma admitted to the ED of a university hospital were analyzed, the rate of penetrating trauma $(15 \%)$

Table 2. Logistic regression analysis of factors affecting mortality

\begin{tabular}{lcccccc}
\hline Factor & Coefficient & Standard error & Wald $\mathrm{X}^{2}$ & $\mathrm{p}$ & Odds ratio & $95 \% \mathrm{Ci}$ \\
\hline Blunt injury & 1.672 & 0.63 & 6.93 & 0.008 & 5.32 & $1.53-18.48$ \\
ISS $>22$ & 1.83 & 0.47 & 15.04 & 0.0001 & 6.27 & $2.48-15.88$ \\
GCS $<13$ & 1.61 & 0.43 & 13.60 & 0.0001 & 5.03 & $2.13-11.87$ \\
TRISS $\leq 84.5$ & 2.44 & 0.47 & 25.9 & 0.0001 & 11.5 & $4.5-29.13$ \\
\hline
\end{tabular}




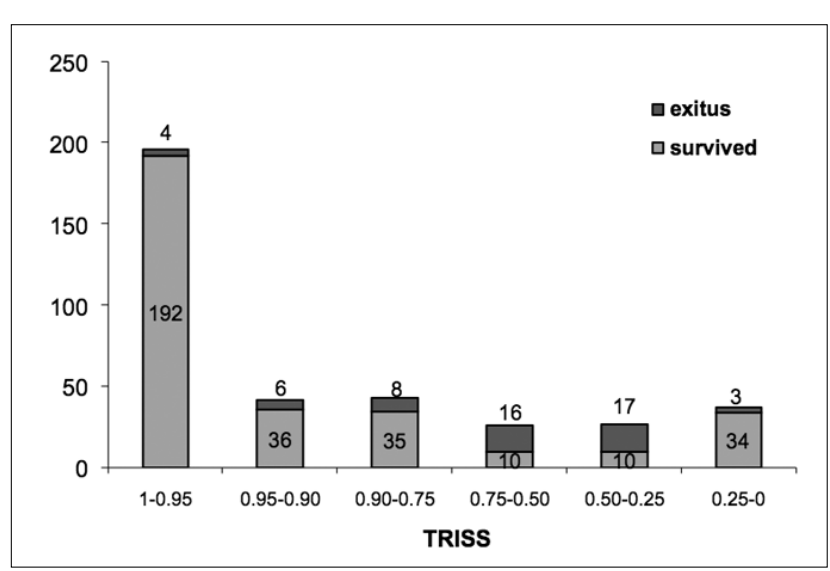

Fig. 4. Distribution of TRISS among existus and surviving cases.

was observed to be lower than the data of the United States of America (USA), but higher than data of some European countries. ${ }^{[7]}$ The majority of our cases $(81 \%)$ were young adult and male patients, and isolated thoracic trauma was detected in one-third of them. In the majority of the rest of the cases, thoracic trauma was associated with injuries to more than one organ system. Logistic regression analysis was used in determining the most important factor affecting mortality, and blunt injury and levels of ISS $>22$, GCS $<13$ and TRISS $<85 \%$ were found to be the most important prognostic factors. The etiologic factors of thoracic trauma may vary between countries. The presence of blunt trauma is almost always a sign of a severe trauma. ${ }^{[8]}$ Penetrating injuries, especially firearm injuries, can be lethal. ${ }^{[9]}$ Single thoracic traumas were observed in only one-third of cases; associated injuries were present in most of our cases. ISS score was found to be $\geq 25$, defined as very severe trauma, in $48 \%$ of cases. The most prevalent pathology was single or multiple rib fracture, seen in $57 \%$ in our series. This rate was reported as $35-40 \%$ in numerous series. Rib fracture rate was found to be $71 \%$ in the study performed by Segers et al. ${ }^{[10]}$ Most cases of thoracic traumas are referred to our hospital, which can explain the high rib fracture rate in our study. The other possible cause is the difference in trauma mechanism. The rate of cases with single rib fracture was $31 \%$, which seems concordant with the literature. Absence of large blood vessel injuries in our study can be explained by the death of such cases at the site of trauma occurrence. Similarly, no case with large blood vessel injury was reported in another series reported from our country. ${ }^{[4]}$ The mortality rate was found to be $22 \%$ in this study. This rate varies between $9.4 \%$ and $20 \%$ in the literature. ${ }^{[5]}$ The high mortality rate in our study can be explained by the presence of cases with severe traumas. The mean ISS was reported to be 16 , with a mortality rate of $9.5 \%$, by Kulshrestha et al. ${ }^{[11]}$; however, an ISS of 22 was detected in our series. Age was determined to be an effective factor for mortality in many thoracic traumas. In many studies, even a single rib fracture was reported to be a cause of death in cases over 70 years of age. ${ }^{[4]}$ In a study by Sirmali et al., ${ }^{[12]}$ mortality and morbidity rates were found to be $67.7 \%$ and $94.4 \%$, respectively, in elderly cases (over 60 years of age) with rib fracture. The threshold value for age was found as 52 with ROC analysis in our study investigating all thoracic traumas. We found a mortality rate of $35 \%$ in cases over 52 year of age and of $20 \%$ in patients younger than 52 years, and this rate was significant in the univariate analysis. However, in our study, age was not an independent variable affecting mortality in logistic regression analysis. Although age is an important factor in predicting mortality in thoracic traumas, our study exhibits that the most important factors are accompanying injuries and blunt injuries. In blunt thoracic traumas, it is crucial to detect the accompanying injuries and determine priority of treatment. In $75 \%$ of cases with thoracic trauma, other parts of the body are injured in addition to the thorax injuries. ${ }^{[8,13]}$ Isolated thorax injuries have been reported quite rarely, as in our series. Extremity, head, long bone and vertebral fractures, and abdominal injury were accompanying in most of the patients. These associated injuries affect mortality and morbidity to an important extent. In addition to hypoxia, hypercapnia and hypotension, thoracic traumas have negative effects on increased intracranial pressure in brain injuries by cerebral venous congestion developing due to decreasing venous return. ${ }^{[14]}$ Low GCS $(\mathrm{GCS}<8)$ together with thoracic trauma was found as the most effective cause of death in a study performed by Kulshrestha et al. ${ }^{[11]}$ In our study, GCS $<13$ was determined as one of the factors affecting mortality. Although the etiology of cases with thoracic trauma exhibits variation, the rate of blunt injuries is higher than that of penetrating injuries, and they have a higher mortality rate as well. In our study, $85 \%$ of the cases had blunt and $15 \%$ had penetrating injuries. Imamoglu et al. ${ }^{[15]}$ reported $59.1 \%$ blunt thoracic injury and $36.4 \%$ penetrating thoracic injuries in their study. In another study performed in Turkey, these rates were determined as $75 \%$ to $25 \% .^{[16]}$ On the other hand, Hill et al. ${ }^{[17]}$ found the rate of blunt thoracic injury as $96.3 \%$ and of penetrating thoracic injury as $3.7 \%$. Early grading of severity of injury in cases with thoracic trauma is extremely important in the prediction of development of complications and possibility of mortality, as in all traumas. ${ }^{[18]}$ Numerous scoring systems are used for grading thoracic traumas. TRISS analysis is a mathematical method examining two trauma scoring systems, age and the trauma mechanism together, which provived an important development in the evaluation of traumatic cases. The differentiation of preventable and unpreventable cases can be performed with this system. ${ }^{[19]}$ All records of 
the cases who died despite having a survival probability of $>50 \%$ can be re-examined, and causes of death and medical errors can be analyzed using this system. There were 34 cases of unexpected death in our study; yet, the actual causes of death of these cases could not be analyzed exactly. For our hospital, the threshold value was found as $85 \%$ for TRISS, which is quite high. Results exhibit that our preventable death rates are high in cases with thoracic trauma. Arrangements of in-hospital and prehospital organizations will reduce this rate; in fact, in a previous study performed in our center, we showed that even simple improvements in organization and education may reduce this rate. ${ }^{[20]}$

The management of patients with serious thoracic traumas necessitates multi-disciplinary teamwork. Blunt injury, ISS $>22$, GCS $<13$ and TRISS $<85 \%$ are the most important factors affecting mortality. In the presence of these factors, patients should be evaluated in the high- risk group, and aggressive diagnosis and treatment methods should be preferred. TRISS modelrelated case analysis will detect the errors and provide improvement in terms of patient care.

\section{REFERENCES}

1. Canturk NZ, Utkan NZ, Yildırır C, Icli F, Dulger M. The prognostic factors in patients with blunt abdominal trauma. Ulus Travma Acil Cerrahi Derg 1996;2:136-40. [Article in Turkish]

2. Ahmet R, Karagulle E, Karakaya K, Gokce F, Abcı I. Our trauma cases of the last nine years. Ulus Travma Acil Cerrahi Derg 2001;7:91-5. [Article in Turkish]

3. Demetriades D, Velhamos GC. Penetrating injuries of the chest: Indications for operations. Scant J Surg 2002;91:41520.

4. Soysal O. Blunt torax trauma. In: Yüksel M, Kalaycı G, Yüksel M, editors. Thorax surgery. 1st ed. Istanbul: Bilmedya Group; 2001. p. 447-64. [In Turkish].

5. Champion HR, Sarıbeyoglu K. Trauma score. In: Ertekin C, Taviloğlu K, Kurdoğlu M, Güloğlu R, editors. Trauma. 1st ed. Istanbul: Istanbul Medikal; 2005. p. 72-82. [In Turkish]

6. Boyd CR, Tolson MA, Copes WS. Evaluating trauma care: the TRISS method. Trauma Score and the Injury Severity Score. J Trauma 1987;27:370-8.
7. Batisella FD, Benfield JR. Blunt and penetrating injuries of the chest wall, pleura and lungs. In: Shields TW, LoCicero J 3rd, editors. General thoracic surgery. 5th ed. Philadelphia: Lippincott Williams \& Wilkins; 2000. p. 815-31.

8. Shorr RM, Crittenden M, Indeck M, Hartunian SL, Rodriguez A. Blunt thoracic trauma. Analysis of 515 patients. Ann Surg 1987;206:200-5.

9. Crawford WO Jr. Pulmonary injury in thoracic and non-thoracic trauma. Radiol Clin North Am 1973;11:527-41.

10. Segers P, Van Schil P, Jorens P, Van Den Brande F. Thoracic trauma: an analysis of 187 patients. Acta Chir Belg 2001;101:277-82.

11. Kulshrestha P, Munshi I, Wait R. Profile of chest trauma in a level I trauma center. J Trauma 2004;57:576-81.

12. Sirmali M, Türüt H, Topçu S, Gülhan E, Yazici U, Kaya S, et al. A comprehensive analysis of traumatic rib fractures: morbidity, mortality and management. Eur J Cardiothorac Surg 2003;24:133-8.

13. Basoğlu A, Akdag AO, Calik B, Demircan S. Thoracic trauma: an analysis of 521 patients. Ulus Travma Acil Cerrahi Derg 2004;10:42-6. [Article in Turkish]

14. Jones R, Gage A, Watchel P. Abdominal trauma. In: Pausada L, Osborn H, David L. Emergency medicine. Williams \& Wilkins; 1997. p. 134-72.

15. Imamoglu O, Onel M, Enginel T. Management of thorax trauma: Evaluation of 110 patients. The Turkish Journal of Thoracic and Cardiovascular Surgery 1999;10:450-3. [Article in Turkish].

16. Tekinbas C, Eroğlu A, Kurkcuoglu I, Turkyılmaz A, Yekeler E, Karaoglanoglu N. Chest trauma: analysis of 592 cases. Ulus Travma Acil Cerrahi Derg 2003;9:275-80. [Article in Turkish].

17. Hill AB, Fleiszer DM, Brown RA. Chest trauma in a Canadian urban setting--implications for trauma research in Canada. J Trauma 1991;31:971-3.

18. Clark GC, Schecter WP, Trunkey DD. Variables affecting outcome in blunt chest trauma: flail chest vs. pulmonary contusion. J Trauma 1988;28:298-304.

19. Joosse P, Soedarmo S, Luitse JS, Ponsen KJ. Trauma outcome analysis of a Jakarta University Hospital using the TRISS method: validation and limitation in comparison with the major trauma outcome study. Trauma and Injury Severity Score. J Trauma 2001;51:134-40.

20. Ozgüç H, Kaya E, Yünük O, Armağan E, Tokyay R. Outcome of major trauma in a Turkish university hospital: did integrated approach make a difference? Eur J Emerg Med 2000;7:183-8. 